\title{
DESIGNS, MOTIVATIONS AND RESULTS OF ECO-INNOVATION IN RESORTS: A CASE STUDY OF RIO QUENTE RESORTS, GOIÁS, BRAZIL
}

\author{
VANESSA DE OLIVEIRA MENEZES \& VIVIANE APARECIDA SCHOAB \\ Universidade Estadual do Centro-Oeste - UNICENTRO, Campus Irati, Brazil
}

\begin{abstract}
The hospitality industry is part of an economic activity with significant environmental impacts, including carbon dioxide and chlorofluorocarbon (CFC) emissions, high energy, water and food consumption and high levels of waste. To minimize the environmental impact, many hospitality properties are implementing and developing eco-innovations that generate ecological, social, economic and market benefits. This paper examines the reality of eco-innovations in Brazilian resorts, using the case of Rio Quente Resorts, located in Rio Quente, Goiás State, Brazil. To this end, the objective was to verify the eco-innovations developed by Rio Quente Resorts, identifying the designs of existing innovations, motivations for investing in them, and the financial and environmental results of these initiatives. Rio Quente Resorts is one of most traditional in the country, and for decades has invested in eco-innovations, earning recognition for this achievement and winning several awards. This qualitative, descriptive and sectional temporal perspective used the analysis of thematic content, with documentary research as a data collection instrument, drawing on Rio Quente's sustainability reports and a semistructured interview with the company's Environmental Manager. The analysis was conducted by triangulating the different data sources to improve the reliability of the results. The study found that Rio Quente Resorts has developed many eco-innovations, mostly end-of-pipe innovations. According to the interviewee, the company's investments in eco-innovation are motivated by its own initiative. The results are measured financially, although they also included an analysis in terms of environmental impact, measuring the decrease in the use of natural resources.
\end{abstract}

Keywords: eco-innovation, designs, motivations, results, rio quente resorts.

\section{INTRODUCTION}

This paper focuses on eco-innovation in resorts. Sustainability has been discussed for decades. However, deeper and more serious studies began in the 1980s, when not only the scientific community but also society as a whole began to rethink their environmental practices and the future of the planet [1]-[6].

Lodging properties are establishments that consume many environmental resources [5][8]. Therefore, it is necessary to pay attention to the environmental issues related to the hospitality industry and invest in innovations that mitigate the negative environmental effects of this sector. According to Frangos [4], the consumer realizes the environmental impacts of the hospitality industry on our planet. Research conducted by the International Hotels Environment Initiative showed that 90 per cent of UK citizens, 70 per cent of Australian, and 30 per cent of Americans accept that the hospitality industry in general has a negative impact on the environment. Therefore, it is necessary to make changes because efficient sustainable development plans can improve a company's reputation, increase employee morale and lead organizations to more sustainable growth and prosperity [4].

This paper examines the reality of eco-innovations in Brazilian resorts, using the case of Rio Quente Resorts, located in Rio Quente, Goiás State, Brazil. The aim was to verify the eco-innovations developed by Rio Quente Resorts, identifying the designs of existing innovations, motivations for investing in them, and the financial and environmental results of these initiatives. 
The Rio Quente Group, located in Rio Quente, Goiás, is dedicated to tourism and leisure activities. With 54 years' experience in the hospitality market, the Group has investments in five segments: hospitality; entertainment; tour operations; vacation ownership and real estate in tourism. To serve all these segments, the Group is divided into 4 pillars: Rio Quente Resorts; Hot Park; Rio Hot Vacation Club and Valetur [9].

Despite the various aspects of the Group, for the purposes of this study, only Rio Quente Resorts will be researched. The Rio Quente Group was chosen, especially Rio Quente Resorts, because it is one of the most traditional and important Resorts in Brazil, and the company has already invested in environmentally sustainable initiatives for decades. Rio Quente Resorts is also involved in social works. It is recognized nationwide and even internationally for its sustainable positioning and has received awards for these initiatives [9].

\section{METHODOLOGY}

A qualitative research strategy was used for the purposes of this study, as it was concerned with gaining an in-depth understanding of the collected data. The study is exploratory and descriptive in nature, based on the exploration of a new subject and describing and classifying the eco-innovations developed at the resort.

The study may be defined as organizational research, since the case in question, Rio Quente Resorts in Goiás, Brazil, is an organization. It was characterized as a case study, which according to Yin [10] is intended "to understand complex social phenomena" (p. 20).

Primary and secondary sources were used for gathering the data. Secondary data were composed of bibliographic research to support, understand concepts and improve knowledge of the subject. Books, scientific articles, online resources and other resources that addressed issues related to environmental sustainability, resorts and the relationship between these two themes were used. Documentary research was also used to collect information from the "Sustainability Guide" and "Sustainability Report 2015/2016", the latter being the most current report made available by the resort. The primary data were gathered through a semistructured interview via Skype with the Environment Manager of Rio Quente Resorts. The interview took place on May 16, 2016. The conversation was recorded and later transcribed for analysis.

To identify the designs of existing innovations, the classification of Carillo-Hermosilla et al. [11] was used as the basis, stating that there are three possible designs of eco-innovation: (1) end-of-pipe innovation; (2) sub-system change; and (3) system change. These typologies will be more clearly explained in Section 3.

Regarding motivation for investing in eco-innovations, seven motivations were considered, based on the studies of Sloan et al. [8]; Frangos [4] and Bohdanowicz and Martinac [12]: (1) Potential cost savings; (2) Improved image and increased market share; (3) Acquisition of competitive advantage; (4) Intrinsic motivation; (5) Increased employee motivation; (6) Guest request; and (7) Advice from other market professionals.

The analysis was conducted by triangulating the different data between the theoretical and document research and the interview to improve the reliability of the results. The information was also crossed with the theoretical basis. Some of the content was presented in tables to facilitate the reader's understanding. 


\section{SUSTAINABILITY}

Sustainability is currently one of the most widely discussed themes in the world [1], [5], [7]. However, the issue began to attract greater attention in the 1960s [3], when speculation over environmental first emerged.

For sustainability to exist, all the needs of current consumers must be met without the loss of resources for future generations. The mass consumerism experienced today needs to be reevaluated and reprogrammed. For this reason, greater awareness and planning of every aspect of society are required.

One way to mitigate the effects of the use of natural resources is by developing and applying eco-innovation.

According to the Organization for Economic Co-Operation and Development (OECD) [13], eco-innovation is an innovation that results in reduced environmental impact, regardless of whether this effect is intentional or not. The scope of eco-innovation can go beyond the conventional limits of companies to innovate and involve a broader social regime, which causes changes in sociocultural norms and institutional structures.

According to Carillo-Hermosilla et al. [11], eco-innovation can be defined through three different designs: (1) the addition of a new component, which is the development of additional components for improving the environmental quality of an existing product or good, minimizing or repairing a negative impact without necessarily changing the process or system (end-of-pipe); (2) change in the subsystem, intended to reduce negative impacts, creating different goods and services using fewer resources, thus generating minimum waste and pollution, using eco-efficiency; and (3) change in the system, which stands out as a radical change, as it modifies the whole system and its components.

End-of-pipe eco-innovations are considered reactive strategies because they do not require the company to develop skills or abilities in the production of new technologies or environmental processes. The company, in this case, only invests in corrective technologies to remedy problems and react to regulatory impositions, not considering this practice as an opportunity for organizational improvement [14], [15]. However, for more significant changes, proactive actions are required. Proactive strategies are considered preventive postures to address environmental issues and impacts through the conscious use of natural resources, continuously adapting products and production processes to reduce levels below legal requirements [16]. Proactive actions are related to radical innovations and are decisive in determining the environmental impact of innovation. Menezes [6] conducted a study at three global hotel chains to understand the environmental innovations in the hospitality industry. According to the research data, most of the innovations of these companies are endof-pipe. Initiatives such as the installation of double-outlet sanitary vessels to reduce water consumption and waste separation are examples of the most common eco-innovations in these hotel chains.

\section{RESORTS AND ECO-INNOVATION}

According to the Brazilian Ministry of Tourism (Brazil) [17], a resort is a hotel with infrastructure for leisure and entertainment that provides aesthetic services, physical activities, recreation and interaction with nature in the property itself. Cordeiro et al. [18] explain that a resort is a beach-like tourism product. Its most salient characteristic is concern over keeping guests within the lodging property, so that all their needs can be satisfied by and on the property itself. One of the strategies to achieve this goal is the adoption of the allinclusive system.

Petrocchi [19] states that resorts should be located in areas of conservation or environmental balance. They should be planned through environmental and land impact 
studies, with an undeveloped area as well as an entertainment and leisure infrastructure superior to similar properties and offering luxury category services.

The term resort originated in World War II, "when people start looking for safe places where they could enjoy everything they wanted to do in a single space" (p. 3). However, the beginnings of resorts can be traced back to the traditions of Roman civilization and public baths [20].

According to Coriolano (2006) cited by Cordeiro et al. [18], resorts in Brazil originated in 1952. Brazilian resorts (such as Transamérica, on Ilha de Comandatuba, Club Med Itaparica, both in Bahia, as well Club Med Rio das Pedras, in Mangaratiba, Rio de Janeiro, Barra de São Miguel, in Praia do Francês, Maragogi, Alagoas, Pipa and Extremoz, in Rio Grande do Norte, Angra dos Reis and Búzios, both in Rio de Janeiro, and Maria Farinha, in Pernambuco) are emblematic in Brazil and open the market to other properties in different parts of the country.

The main representative of the category in Brazil is the Associação Brasileira de Resorts (ABR) (Brazilian Association of Resorts). Founded in 2001, the Association has 48 members, located in 13 Brazilian states, totalling 13,974 beds, employing 19,926 people and receiving more than 5 million tourists in 2016 [20].

Like all other types of lodging properties, resorts have also shown concern over the environmental management of their resources and have created or implemented management systems or eco-innovations to reduce the impact of the use of resources in their daily operations.

Dias [2] claims that "undoubtedly, this is the most rapidly evolving sector in the world" (p. 55). However, there are other opinions on this issue. Gonçalves [5] points out that "there is trend in which the pursuit of environmental quality is ceasing to be a problem and becoming a factor of business competitiveness and, above all, social responsibility" (p. 33). Simple initiatives or innovations such as environmental care, minimization of waste, conservation and the use of sustainable practices (reduce, reuse, recycle) can be used in hospitality on a daily basis.

To reduce the use of electricity and increase efficiency, it is possible to use occupancy sensors, turn heating, lighting and cooling units on or off, replace interior/exterior lamps with LED lamps wherever possible and install a reflective roof and solar lamps. Other alternative include disconnecting computers, electronic equipment, coffee machines, POS systems and all small appliances when not in use, lowering the thermostat by 2 degrees in winter and raising it 2 degrees in summer, using energy-saving window film in rooms and in public and back of the house spaces. It is also possible to stop draughts with sealing and isolating around windows and doors and install energy curtains in freezer rooms and install a reflective roof, use solar lamps and solar energy and replace old vent hoods in the kitchen with smart new ones [4], [6]-[8].

Possibilities for waste reduction include implementing waste-stream audits, controlling food waste (donations, composting), recycling as much as possible and implementing a guestroom and back of the house recycling program. It is also possible to reuse furniture, recycled flooring and wood from sustainably managed forests, and recycle paper, plastic, glass and aluminium, and other materials. Other possibilities include recycling/reusing materials, implementing a refillable amenity dispenser, guestroom soap and amenity donation, textile and mattress recycling programs, using bio-degradable hotel key cards, and creating guest and employee awareness programs to produce less waste [4], [6]-[8], [22].

To reduce and reuse water, it is also possible to buy water efficiency gadgets, use laundry equipment with microprocessor controls and install an ozone system, check leaking valves and repair faucets and leaky toilets, and install waterless urinals in employee and public 
restrooms. Other possibilities include the reuse of shower and swimming pool water, use of biodegradable detergents, double valves in discharges and smart showers, constant control of irrigation systems, cooling towers and swimming pools, and installing sub water-line meters recording water usage. It is also possible to avoid "watering" parking lots and roads and use alternative rain gauge systems. Other alternatives are the implementation of rainwater harvesting systems, bio-retention basins and green roofs [4], [6], [8].

For food and beverages (F\&B), the alternatives include embracing the local community and flavours, setting up an organic vegetable garden and farm, and not overusing food sources like seafood. It is also possible to choose seasonal products, reuse products in other recipes, develop relationships with local purveyors and chefs and select environmentally conscious suppliers [4], [6], [8].

In addition to the initiatives and technologies presented in the previous paragraphs, a number of new technologies can be used or implemented in the hospitality industry to reduce the consumption of resources and even change the way people stay in a lodging property, with an emphasis on customer experience.

\section{DATA PRESENTATION AND ANALYSIS OF RIO QUENTE RESORTS CASE STUDY}

Rio Quente Resorts, formerly Pousada do Rio Quente, is located 28 kilometres from Caldas Novas, Goiás State, Central-western Brazil. Founded in 1964, the complex has a total area of $497,000 \mathrm{~m}^{2}$ with 18 thermal hot springs. It has the largest artificial and natural water beach in the world, Praia do Cerrado, and Hot Park is one of the largest water parks in Brazil, with swimming pools and complete leisure infrastructure [9].

\subsection{Rio Quente resorts eco-innovations}

According to the "Sustainability Report 2015/2016", the Rio Quente Sustentável Program is based on six initiatives: Water Resource Management, Atmospheric Emission Management, Natural Resource Management, Construction Management, Solid Waste Management and Social Responsibility. The initiatives and eco-innovations developed by the Resort are shown in Table 1.

Table 1: Initiatives and eco-innovations of Rio Quente Resorts. (Source: Rio Quente Resorts, 2018; Interview, 2016.)

\begin{tabular}{|c|c|c|c|c|c|}
\hline Water & Emissions & $\begin{array}{c}\text { Natural } \\
\text { resources }\end{array}$ & Construction & Solid waste & $\begin{array}{c}\text { Social } \\
\text { responsibility }\end{array}$ \\
\hline $\begin{array}{l}\text { Installation of a } \\
\text { Water Monitor } \\
\text { System - Water } \\
\text { Monitoring }\end{array}$ & $\begin{array}{l}\text { Installation of a } \\
\text { Greenhouse Gas } \\
\text { Emission } \\
\text { Monitor System } \\
\text { - Greenhouse } \\
\text { Gas Emissions } \\
\text { Inventory in } \\
\text { accordance with } \\
\text { the guidelines of } \\
\text { the Brazilian } \\
\text { GHG Protocol }\end{array}$ & $\begin{array}{c}\text { Development } \\
\text { of a Fauna and } \\
\text { Terrestrial } \\
\text { Monitor } \\
\text { System - Fauna } \\
\text { and terrestrial } \\
\text { vertebrate } \\
\text { monitoring }\end{array}$ & $\begin{array}{l}\text { New Water } \\
\text { Destination } \\
\text { System - Water } \\
\text { rainfall } \\
\text { drainage } \\
\text { system in non- } \\
\text { erosive } \\
\text { channels }\end{array}$ & & $\begin{array}{l}\text { Employees' } \\
\text { qualification } \\
\text { and training }\end{array}$ \\
\hline
\end{tabular}


Table 1: Continued.

\begin{tabular}{|c|c|c|c|c|c|}
\hline Water & Emissions & $\begin{array}{l}\text { Natural } \\
\text { resources }\end{array}$ & Construction & $\begin{array}{r}\text { Solid } \\
\text { waste }\end{array}$ & $\begin{array}{c}\text { Social } \\
\text { responsibility } \\
\end{array}$ \\
\hline $\begin{array}{c}\text { New Water } \\
\text { Treatment } \\
\text { System - } \\
\text { Pool } \\
\text { effluents } \\
\text { are } \\
\text { disinfected } \\
\text { with } \\
\text { standard } \\
\text { bathing } \\
\text { water } \\
\text { before } \\
\text { being } \\
\text { sent to the } \\
\text { Água } \\
\text { Quente } \\
\text { riverbed }\end{array}$ & $\begin{array}{c}\text { Use of Solar Energy - } \\
\text { Installation of Solar } \\
\text { Energy panels and } \\
\text { poles }\end{array}$ & $\begin{array}{l}\text { Vegetable } \\
\text { culture with } \\
\text { less } \\
\text { pesticide, } \\
\text { serving } \\
100 \% \text { of } \\
\text { property’s } \\
\text { consumption }\end{array}$ & $\begin{array}{c}\text { New Waste } \\
\text { Treatment } \\
\text { System - } \\
\text { Contaminated } \\
\text { waste } \\
\text { treatment } \\
\text { generated by } \\
\text { washing } \\
\text { brushes, } \\
\text { rollers and } \\
\text { other tools }\end{array}$ & $\begin{array}{l}\text { Reuse of } \\
\text { Organic } \\
\text { Waste - } \\
\text { Organic } \\
\text { waste } \\
\text { composting } \\
\text { power plant } \\
\text { used in } \\
\text { kitchen } \\
\text { gardens and } \\
\text { gardens }\end{array}$ & $\begin{array}{l}\text { Staff have the } \\
\text { opportunity to } \\
\text { enjoy the } \\
\text { Resort with } \\
\text { their family } \\
\text { once a month }\end{array}$ \\
\hline $\begin{array}{c}\text { New Water } \\
\text { Treatment } \\
\text { System - } \\
\text { Own } \\
\text { Sewage } \\
\text { Treatment } \\
\text { Station for } \\
\text { effluents } \\
\text { from the } \\
\text { kitchen, } \\
\text { laundry, } \\
\text { toilets, } \\
\text { service } \\
\text { area, etc. }\end{array}$ & $\begin{array}{l}\text { Use of new Energy } \\
\text { Sources - Biogas } \\
\text { production by the } \\
\text { Biodigester of the } \\
\text { Sewage Treatment } \\
\text { power plant used as an } \\
\text { energy source }\end{array}$ & $\begin{array}{l}\text { Maintenance } \\
\text { of gardens } \\
\text { with native } \\
\text { species } \\
\text { nurseries }\end{array}$ & $\begin{array}{c}\text { New } \\
\text { Construction } \\
\text { Waste } \\
\text { Destination } \\
\text { System - } \\
\text { Reuse of } \\
\text { construction } \\
\text { waste }\end{array}$ & & $\begin{array}{c}\text { New Personnel } \\
\text { Policy - } \\
\text { Employees' } \\
\text { recognized } \\
\text { with career } \\
\text { plan }\end{array}$ \\
\hline \multirow[t]{4}{*}{$\begin{array}{l}\text { Water } \\
\text { reuse for } \\
\text { irrigation } \\
\text { of plants } \\
\text { and } \\
\text { gardens }\end{array}$} & $\begin{array}{l}\text { Tree irrigation through } \\
\text { solar drip }\end{array}$ & $\begin{array}{c}\text { Change of } \\
\text { Energy } \\
\text { Technologies } \\
\text { - Use of } \\
\text { LED } \\
\text { underwater } \\
\text { lamps } \\
\text { in swimming } \\
\text { pools } \\
\end{array}$ & & & $\begin{array}{c}\text { New Personnel } \\
\text { Policy - } \\
\text { Support for } \\
\text { leadership } \\
\text { development }\end{array}$ \\
\hline & Chiller installation & & & & $\begin{array}{c}\text { New Personnel } \\
\text { Policy }-360- \\
\text { degree } \\
\text { competence } \\
\text { assessment } \\
\end{array}$ \\
\hline & $\begin{array}{l}\text { Resort's drinking } \\
\text { water supplied using } \\
\text { pneumatic valves }\end{array}$ & & & & $\begin{array}{c}\text { Community } \\
\text { awareness and } \\
\text { education } \\
\text { activities }\end{array}$ \\
\hline & $\begin{array}{l}\text { Installation of Energy } \\
\text { Monitor System - } \\
\text { Individual energy } \\
\text { meters and mapping of } \\
\text { connected equipment }\end{array}$ & & & & $\begin{array}{l}\text { Assistance and } \\
\text { donation of } \\
\text { products to the } \\
\text { community }\end{array}$ \\
\hline
\end{tabular}


Table 1: Continued.

\begin{tabular}{|c|c|c|c|c|c|}
\hline Water & Emissions & $\begin{array}{c}\text { Natural } \\
\text { resources }\end{array}$ & Construction & Solid wastes & $\begin{array}{c}\text { Social } \\
\text { responsibility }\end{array}$ \\
\hline & $\begin{array}{l}\text { Energy } \\
\text { purchased on } \\
\text { the free } \\
\text { market, } \\
\text { favouring } \\
\text { renewable } \\
\text { sources and } \\
\text { reducing hotel } \\
\text { generators' } \\
\text { diesel } \\
\text { consumption }\end{array}$ & & & & \\
\hline & $\begin{array}{l}\text { Purchase and } \\
\text { use of eco- } \\
\text { friendlier } \\
\text { technologies } \\
\text { in transport - } \\
\text { use of electric } \\
\text { bus }\end{array}$ & & & & \\
\hline
\end{tabular}

Table 1 shows that the resort is taking a significant amount of actions related to sustainability. It is interesting to note that the initiatives undertaken by the resort are not only linked to the environment. They are also related to economic and social sustainability. This triad forms the triple bottom line. However, the data show that most of the eco-innovations of Rio Quente Resorts can be classified as end-of-pipe. In other words, these are only investments in corrective technologies to remedy existing problems such as monitoring water use and fauna and terrestrial vertebrates, reuse of materials and adequate disposal of the waste produced by the resort and substituting common light bulbs with LED. Some innovations such as the sewage treatment power plant, the use of solar panels and poles, the use of biogas produced by the biodigester of the sewage treatment power plant as an energy source and the organic waste composting power plant can be understood as sub-innovation-systems. However, no system innovation was found, a radical innovation that would change the hospitality industry as a whole. This result is in keeping with the study of Menezes [6]. This author analysed three global hotel chains and found that most of their innovations were endof-pipe. Therefore, the hotel industry is still engaged in corrective measures to remedy problems and only reacts to existing situations.

\subsection{Motivations}

According to the interview, Rio Quente Resorts' commitment to environmental sustainability date back to its founding in 1964. In 1987, the first sewage plant was built in partnership with the municipality. However, the project was formally structured in 1999, with preparations to implement the ISO 14001 environmental management system, which has been operating in the Resort since 2001. For this, improvements were sought in the management system and through different strategies. This shows that when it comes to motivation, as raised by Sloan et al. [8] and Bohdanowicz and Martinac [12], the Rio Quente Resorts had an intrinsic motivation since the company has always been concerned with environmental sustainability, even before the environment became the subject of international debate. 
The innovations made at the resort are developed by the Environment Agency, a team consisting of in 13 professionals in a department established within the resort for this purpose. The team is divided into nuclei (environmental monitoring, technical management, maintenance and project development, education and social communication). Each team develops its initiatives according to the resort's needs, working alongside the other nuclei. When an initiative is deemed reasonable and of interest to the resort and falls within its budgetary parameters, it is approved and instituted by the environmental management.

\subsection{Financial and environmental results}

According to the interviewee, the major goal of Rio Quente Resorts when investing in ecoinnovations is to raise awareness and concern over the environment, and all such innovations have been the product of the company's own initiative for decades. These innovations have had positive results, not only for the environment, but also in terms of reducing costs.

The results achieved through the resort's innovations are shown in Table 2.

Table 2: Financial and environmental results. (Source: Rio Quente Resorts, 2018.)

The solar panels save $43,560 \mathrm{kWh} /$ month, equivalent to the electricity consumption of 130 regular houses.

The biogas accumulated in sewage treatment has the potential to generate $280 \mathrm{kWh} /$ day or 8,400 $\mathrm{kWh} /$ month of electricity, equivalent to savings of $47 \%$.

The installation of underwater LED lamps in the pools means savings of $85.5 \%$ in the energy consumed at these points, or $2,136.64 \mathrm{kWh} /$ month, equivalent to the electricity consumption of 6 regular houses.

The installation of the chiller led to a 3\% reduction in general energy consumption. Compared with the energy consumption of the old air conditioning system, the new system saves $16.3 \%$ or $19,676.16 \mathrm{kWh}$ /month, equivalent to the electricity consumption of 58 regular houses.

The energy monitoring system led to a reduction of $1,198,632.42 \mathrm{kWh}$, or $10.7 \%$, compared with the energy consumption for the years 2014 x 2015 .

From 2015 to 2016, diesel consumption was reduced by 201,021.41 litres, generating a reduction of 492 tCO2e of Scope 1 emissions, emissions generated by residues and fertilizers, fugitive emissions, etc.

The use of the electric bus generated a reduction in diesel consumption of $\mathrm{R} \$ 3,739.57$ (US \$ 1,161.00) and $\mathrm{u} 3.72$ tons of $\mathrm{CO}_{2}$ equivalent in the atmosphere, a result measured in a period of only 20 days.

Planting of 4,500 seedlings of native plants between 2010 and 2016.

$100 \%$ of the vegetables consumed by the guests are locally produced with the lowest number of agrochemicals, decreasing the cost of food purchases and providing guests with higher quality products. Sale of part of solid waste such as metal, glass, lubricating oil, vegetable oil, ferrous and plastic scrap and electronic scrap to recycling companies.

Donation of paper, cardboard and plastic to recycling companies.

The composting power plant can produce $1,300 \mathrm{~kg}$ /day of fertilizer from the organic waste generated in restaurants, tree pruning, shredded coconut fruit and ash generated in the laundry boiler to be used in the kitchen garden and landscaping of the resort. 
The economic benefits presented above are mostly related saving costs, mainly in terms of electricity and diesel consumption. However, environmental benefits, such as the correct disposal and reuse of organic waste, water treatment and planting of native seedlings around the resort should also be emphasized as positive results. The social benefits, although not shown in Table 2, should also be highlighted as social responsibility initiatives by the resort, leading to greater appreciation and commitment of employees to the company and greater awareness of the community with regard to the importance of preserving the environment. These initiatives can have medium and long-term results. This shows that the eco-innovations of Rio Quente Resorts result in benefits in several segments.

\section{CONCLUSION}

This paper examines the reality of eco-innovations in Brazilian resorts, using the case of Rio Quente Resorts, located in Rio Quente, Goiás State, Brazil. According to the documents and interview, the eco-innovations developed at the resort are based on six aspects: Water Resource Management, Atmospheric Emission Management, Natural Resource Management, Solid Waste Management and Social Responsibility. The study found that the resort has developed many eco-innovations, mostly end-of-pipe, although there have also been sub-system eco-innovations. According to the interviewee, the company's investment in eco-innovation is motivated by the resort's own initiative. However, eco-innovations lead to positive financial and social consequences, and these results are measured financially and environmentally. The economic benefits are related in great part to cost savings, mainly in electric energy and diesel consumption. As for the environmental impact, it is measured by the decrease in the use of natural resources.

Finally, this study was not intended as an exhaustive discussion on the subject, however rather to encourage further research at different Brazilian resorts to gauge whether the reality of Rio Quente Resorts is similar to other Brazilian hotel developments.

\section{ACKNOWLEDGEMENTS}

We would like to express our very great appreciation to the Rio Quente Group for granting us an interview. Their willingness to give their time so generously was greatly appreciated. We would also like to thank the Resort for providing us with data and authorizing the use of the company's name in this paper.

\section{REFERENCES}

[1] Boff, L., Ecologia: grito da terra, grito dos pobres, Ática: São Paulo, 1995.

[2] Dias, R., Marketing ambiental: ética, responsabilidade social e competitividade social e competitividade nos negócios, Atlas: São Paulo, 2009.

[3] Dias, R., Gestão ambiental. Responsabilidade social e sustentabilidade. 2. ed. rev. aval., Atlas: São Paulo, 2011.

[4] Frangos, N., Environmental management and sustainability strategies for hospitality organizations. E-Hoteliers Viewpoints 27 Jul. 2017. https://ehotelier.com/insights/ 2017/07/27/corporatesocialresponsibility/?utm_source=Newsletter\&utm_campaign= 0d42c897a3Weekly_Wrapup_20170709\&utm_medium $=$ email\&utm_term $=0$ e17a7b f7c4-0d42c897a3326513285\&mc_cid=0d42c897a3\&mc_eid $=9 d 773853 \mathrm{c} 5$. Accessed on: 29 Jul. 2017.

[5] Gonçalves, L.C., Gestão ambiental em meios de hospedagem, Aleph: São Paulo, 2004.

[6] Menezes, V.D.O., Inovação para a Sustentabilidade Ambiental e Estratégia Competitiva em Redes Hoteleiras Globais: Elaboração de um Modelo Conceitual de 
Relação. p. 216. PhD thesis, Business Administration Program, Universidade Positivo, Curitiba, 2015.

[7] Perardt Farias, A.P. \& Menezes, V.D.O., Iniciativas Ambientalmente Sustentáveis em Redes Hoteleiras: Estudo de caso de um empreendimento hoteleiro típico. Festival de Turismo das Cataratas do Iguaçu, 2013.

[8] Sloan, P., Legrand, W. \& Chen, J., Sustainability in the Hospitality Industry. Principles of Sustainable Operations, 2nd ed., Routledge: New York, 2013.

[9] Rio Quente Resorts. Dados Gerais. https://rioquenteresorts.com.br/grupo-rio-quente. Accessed on: 1 Feb. 2018.

[10] Yin, R., Estudo de caso: planejamentos e métodos, Trad. Daniel Grassi, 3rd ed., Bookman: Porto Alegre, 2005.

[11] Carrillo-Hermosilla, J., González, P.R. \& Könölla, T., Ecco-Innovation. When sustainability and competitiveness shake hands, Palgrave Macmillan: London, 2009.

[12] Bohdanowicz, P. \& Martinac, I., Attitudes towards sustainability in chain hotels Results of a European survey, 2003. http://storage.globalcitizen.net/data/ topic/knowledge/uploads/2012022312648705.pdf. Accessed on: 25 Jan. 2015.

[13] OECD, Organisation for economic co-operation and development. Sustainable manufacturing and eco-innovation: framework, practices and measurement. Synthesis Report, Paris: OCDE, 2009. www.oecd.org/dataoecd/15/58/43423689.pdf. Accessed on: 20 Jun. 2010.

[14] Buysse, K. \& Verbeke, A., Proactive environmental strategies: a stakeholder management perspective. Strategic Management Journal, 24(5), pp. 453-470, 2003.

[15] Barbieri, J.C., Desenvolvimento e meio ambiente: as estratégias de mudanças da Agenda 21, 5th ed., Vozes: Petrópolis, 2002.

[16] Sharma, S., Managerial interpretations and organizational context as predictors of corporate choice of environmental strategy. Journal Briarcliff Manor, Academy of Management, 43, pp. 681-697, 2000.

[17] Brasil. Ministério do Turismo. Classificação do Meios de Hospedagem. www.classificacao.turismo.gov.br/MTURclassificacao/mtursite/Entenda?tipo=2. Accessed on: 3 Feb. 2018.

[18] Cordeiro, I, Bento, E. \& Britto, C., Turismo e desenvolvimento sustentável: considerações sobre o modelo de resorts no litoral nordeste do Brasil. Caderno Virtual de Turismo. Rio de Janeiro, 11(1), pp. 355-369, 2011.

[19] Petrocchi, M., Hotelaria: planejamento e gestão, Futura: São Paulo, 2002.

[20] Roim, T.P.B. \& Gonçalves, A., A nova classificação Hoteleira - Resorts, Revista Científica Eletrônica de Turismo, IX (17), pp. 1-11, 2012.

[21] ABR - Associação Brasileira de Resorts. Dados gerais. https://abr-resortsbrasil. com.br/quem-somos/. Accessed on: 4 Feb. 2018.

[22] Viera, E.D.V., Desperdício em hotelaria: soluções para evitar, EDUCS: Caxias do Sul, RS, 2004.

[23] Almeida, F., O bom negócio da sustentabilidade, Nova Fronteira: Rio de Janeiro, 2002. 